\title{
AN ERROR ANALYSIS OF PHRASAL VERB MISTAKE BASED ON SURFACE STRATEGY TAXONOMY IN ENGLISH WRITING ESSAY
}

\author{
Yosi Marita \\ English Education Department of Prof. Dr. Hazairin, S.H University, Indonesia \\ e-mail:yosi_marita@yahoo.com
}

Received on March, 20 $0^{\text {th }}$, Revised on May, $15^{\text {th }}$, Published on July, $30^{\text {th }} 2020$

\begin{abstract}
The purpose of this study was to find and analyze phrasal verb mistake based on surface strategy taxonomy in English essays written by students. This research was conducted using a qualitative approach with content analysis methods. The data source of this research is the first semester students of the Accounting Program Prof. Dr. Hazairin, SH University in academic year 2019/2020. The data consisted of 24 essays written by students. The results of this study indicate that there are 76 errors from four categories of errors including: obmission, misformation, addition, and misordering. Based on the research findings, it can be concluded that the highest error is found in misformation namely 30 times (86\%). Causing a misperception between the writer and the reader. Therefore phrasal verb is indispensable in writing essays in English.
\end{abstract}

Key Words: Language Error, Error Analisis, Phrasal Verb Essay

\begin{abstract}
ABSTRAK
Tujuan dari penelitian ini adalah untuk menemukan dan menganalisis kesalahan phrasal verb berdasarkan strategi permukaan taksonomi pada esai bahasa Inggris yang ditulis oleh siswa. Penelitian ini dilakukan dengan menggunakan pendekatan kualitatif dengan metode analisis isi. Sumber data dalam penelitian ini adalah mahasiswa semester satu Program Studi Akuntansi Prof. Dr. Hazairin, SH University tahun akademik 2019/2020. Data terdiri dari 24 karangan yang ditulis oleh siswa. Hasil penelitian ini menunjukkan bahwa terdapat 76 kesalahan dari empat kategori kesalahan yaitu: obmission, misformation, penambahan, dan misordering. Berdasarkan temuan penelitian dapat disimpulkan bahwa error tertinggi terdapat pada misformation yaitu 30 kali (86\%). Menyebabkan mispersepsi antara penulis dan pembaca. Oleh karena itu, kata kerja frase sangat diperlukan dalam menulis esai dalam bahasa Inggris.
\end{abstract}

Kata Kunci: Kesalahan Bahasa, Analisis Kesalahan, Esai Phrasal Verb 


\section{INTRODUCTION}

Writing is a skill that can be used to express such a feeling and an idea. Writing needs a number of supporting potential therefore to achieve it needs seriousness, hard will, learning and exercising continuously in such a very long time. Thereby, it is normal if it is said that creating a writing cultural atmosphere will encourage a person to be more creative, active and smart.

Dulay (1982: 277) said that in preparing a writing, we must master a number of component, starting from very simple things, such as selecting words, composing a sentence, up to a rather complicated matters, namely composing a paragraph. Therefore, writing learning process must be able to develop their thinking ability to express their ideas into a form of writing in the form of a writing or essay. As said by Langan (2003:12): Most Important, essay writing will make us a stronger thinker. Writing a solidly reasoned traditional essay requires mental discipline and close attention to a set logical role.

Bearing in mind the importance of learning how to write a writing, it is not surprising that writing an essay is one of the skills which must be studied by student in
English subject. Even, student is obliged to compose a writing, paper, or thesis as graduation requirement. It shows that writing activity occupies a very important position.

The difficulty in writing an essay is possibly because this competency is such a complex proficiency which needs other high level language proficiency. In the book writing with a Purpose, Wilga $(2003: 12)$ said it seems that proficiency to adapt, to manipulate, to sort, to correct, and to evaluate a language plays such a very important role in three processes, namely learning how to read and write, learning a foreign language, and responding a social expectation. Other thing needed by a writer is the knowledge and proficiency to compose a sentence explicitly. Thereby, it is normal if it is said that creating a writing cultural atmosphere will encourage a person to be more creative, active and smart. Students, however, frequently find it difficult in making a writing. Whereas, the factors causing students experience a difficulty among other things are: difficulty in writing clues, both in a language usage or its application in the form of writing grammatical.

Phrasal verb form in writing an essay. This is because of the students' habit of more frequently using general verbs in 
verbal or written communication in English.

Therefore, this research is aimed to know the comprehension discussing the mistakes in using phrasal verb in writing an essay which covers types of mistakes of phrasal verb, mistakes of phrasal verb meaning, mistakes of phrasal verb based on strategic category and to know the causes of mistakes. The mistakes of phrasal verb discussed in this research are the mistakes in the English essay written by students of the first semester students of the Accounting Program Prof. Dr. Hazairin, SH University in academic year 2019/2020.

\section{METHODOLOGY}

This research is a qualitative research by using content analysis method, source of data of this research is in the form of phrasal verb mistakes in the essay of students of the first semester students of the Accounting Program Prof. Dr. Hazairin, SH University in academic year 2019/2020.. The phrasal verb mistake existing in each essay of the student is classified according to the type or category of mistake. Research data is in the form of phrasal verb mistakes existing in the student's essay was analyzed, then interpreted and further conclusion taking process.

Emzir (2010) put forward that content analysis (qualitative) can be in the form of all types of recorded communication (interview transcript, discourse, observation protocol, video tape, and document. The method used in this research is descriptive analysis method in the form of written or verbal words of the persons and the behavior which can be observed, this research gives a description of a situation and condition as clear as possible, without any treatment to the research object.

The population in this research are students of semester the first semester students of the Accounting Program Prof. Dr. Hazairin, SH University in academic year $2019 / 2020$

The samples in this research includes phrasal verb mistake in the form of essay writing in English written by the students of 24 sheets of essay comprising 76 mistakes of phrasal verb sentence.

\section{FINDING AND DISCUSSION}

Phrasal verb mistake based on the surface strategy taxonomy can be concluded that the first position is in misformation category namely 30 times (86\%), followed by the second mistake namely in addition category wherein there are 3 mistakes or 3 times $(8 \%)$ and further in the third position namely mistake in omission category and misordering category in which there are the same number of 
mistake of 9 times (3\%). Thus, it can be concluded that the total number of mistake based on the surface strategy taxonomy is 76 mistakes. thus it can be concluded that phrasal verb error in the sentences made by students will result in impact to the readers, it seen in the diagram 1 Quantity/Percentage of Phrasal Verb Mistake Based on Surface Strategy Taxonomy.

Based on the result, not all students can make a sentence which is grammatically correct which can be used to express something appropriately. Based on initial research result conducted by researchers, it can be concluded that students tend to use general verb form instead of phrasal verb form in writing an essay. This is because of the students' habit of more frequently using general verbs in verbal or written communication in English.

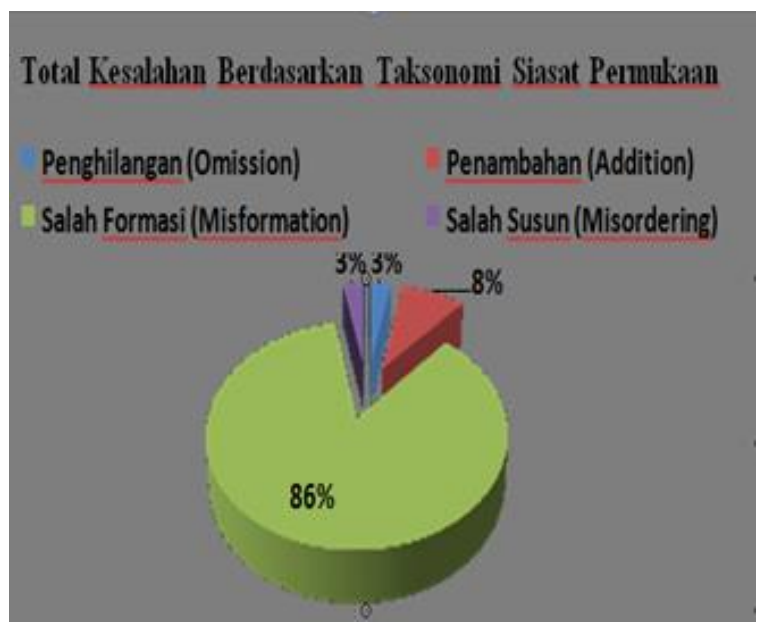

Diagram 1: Quantity/Percentage of Phrasal Verb Mistake Based on Surface Strategy Taxonomy

\section{CONCLUSION}

Based on the findings of the research, it can be concluded that: First, from the kind of phrasal verbs errors; the highest rate of error was In the above table, phrasal verb mistake based on the surface strategy taxonomy can be concluded that the first position is in misformation), followed by the second mistake namely in addition category and further in the third position namely mistake in omission category and misordering category . Thus, it can be concluded that the total number of mistake based on the surface strategy taxonomy is 76 mistakes. thus it can be concluded that phraal verb error in the sentences made by students will result in impact to the readers.

\section{REFERENCES}

Corder, S.P (1981). Error Analysis and Interlanguage. New York: Oxfrord University Press.

Downing, Angela. (1982). English

Grammar. USA: Routledge, Dulay Heidi, at al. Language two. Use: Oxford University Press.

Emzir. (2010). Penelitian Kualitatif Analisis Data. Jakarta: Rajawali Press. Foley, Joseph. ((2010). Jurnal Conference 
Trflin 57th. Bandung.

Heaton, J.B (1989). Writing English Language Test. London: Longman.

James, Carl. (1998). Error in Language Learning and Use Exploring Error Analysis. USA: Longman.

Langan, John. (2003). College Writing

Skill, Media Education. USA:

Mc.Graw-Hill Company.

Mounsey. (2002). Essay and Disertation.

Oxford University Press.

Ozbex, Nurdan. (1995). Integrating

Grammar in the teaching of

Paragraph level composition. English
Teaching Forum 33.

Pateda, Mansoer. (1989). Analisis Kesalahan. Nusa Indah Flores. NTT

Rivers, wilga. (1983). Teaching Foreign Language skill. Chicago: The University of Chicago Press Ltd.

Sinclair. (1994) Dictionary of Phrasal Verb. England: Collins Cobuild.

Wishon, George E. and Julia M. B. (1980). Let's Write English. (revised ed.). New York: Litton Educational Publishing. 